\title{
PROBLEM DAN ALTERNATIF SUDUT PANDANG TERHADAP KLAIM KEBENARAN FILMIS DOKUMENTER
}

\author{
Renta Vulkanita Hasan \\ Program Studi Pengkajian Seni Pertunjukan dan Seni Rupa \\ Sekolah Pascasarjana, Universitas Gadjah Mada \\ No.Hp.: 081328880986, E-mail: E-mail: renta.vulkanita.h@mail.ugm.ac.id \\ G. R. Lono Lastoro Simatupang \\ Program Studi Pengkajian Seni Pertunjukan dan Seni Rupa \\ Sekolah Pascasarjana, Universitas Gadjah Mada \\ No. Hp.: 08122806770,_E-mail: lono_simatupang@yahoo.com \\ Kurniawan Adi Saputro \\ Program Studi Fotografi, Fakultas Seni Media Rekam \\ Institut Seni Indonesia Yogyakarta \\ No.Hp.: 085701103410,E-mail: kurniawan.as@isi.ac.id
}

\begin{abstract}
ABSTRAK
Klaim kebenaran filmis yang berlaku bagi dokumenter perlu diselidiki dengan pertimbangan bahwa notabene gagasan tentang kebenaran filmis diletakkan pada dua aspek, yaitu realitas dan sineas. Penyelidikan dilakukan untuk mengetahui sejauh mana persoalan itu berkembang, serta mencari berbagai kemungkinan atau alternatif untuk menyelesaikan persoalan tersebut. Hasil penyelidikan tersebut menjadi dasar bagi konseptualisasi tentang kebenaran filmis dokumenter dengan cara mempertimbangkan peletakan kebenaran filmis pada aspek lain, di luar realitas dan sineas. Langkah awal penyelidikan fokus kepada literature review. Langkah ini menjadi cara yang efektif untuk menyarikan beberapa pemikiran penting dan mengkritisi pemikiran terkait klaim kebenaran filmis dokumenter. Hasil literature review menunjukkan adanya celah persoalan yang harus diselesaikan terkait klaim kebenaran filmis dokumenter. Persoalan itu muncul karena belum adanya satu gagasan yang secara signifikan menyebut pembacaan kebenaran filmis secara kognitif. Itu artinya, proses kognitif yang berlangsung selama kegiatan menonton belum sepenuhnya dibahas sebagai fokus dalam beberapa kajian tersebut. Problem inilah yang mendasari tawaran alternatif berupa pelibatan penonton untuk membaca kebenaran filmis dokumenter melalui pengamatan terhadap keberadaan unsur filmis di sepanjang alur dan plot. Konseptualisasi ini menemukan istilah bagi cara pandang penonton terhadap klaim kebenaran filmis, yaitu keterpercayaan. Istilah keterpercayaan ini akan dikaji secara khusus sebagai istilah baru bagi klaim kebenaran filmis dokumenter dalam penelitian selanjutnya.
\end{abstract}

Kata kunci: problem, kebenaran, filmis, dokumenter, keterpercayaan

\section{ABSTRACT}

Problem and New Perspective to the Truth Claims of Filmic Documentary. Filmic truth claims that apply to documentaries need to be investigated with the consideration that in fact the idea of filmic truth is placed in two aspects, namely reality and filmmakers. Investigations were carried out to determine the extent to which the problem develops, and to look for various possibilities or alternatives to resolve the problem. The results of these investigations were the basis for the conceptualization of the truth of the filmic documentary by considering the placement of filmic truths on other aspects, outside reality and filmmakers. The initial step of the investigation focused on the literature review. This step was an effective way to extract some important thoughts and to criticize thoughts related to documentary filmic truth claims. The results of the literature review indicated the existence of a problem gap that must be resolved 
related to documentary filmic truth claims. The problem arose because there is no single idea that significantly mentions cognitive reading of filmic truth. That means, the cognitive processes that has taken place during watching activities have not been fully discussed as a focus in some of these studies. It is this problem that underlies an alternative offer in the form of engaging the audience to read the filmic truth of the documentary through observing the existence of the filmic elements along its plot. This conceptualization found a term for the cognitive's perspective on filmic truth claims, namely trustworthiness. This term will be specifically examined as a new term for documentary filmic truth claims in future research.

Keywords: problem, truth, filmic, documentary, trustworthiness

\section{PENDAHULUAN}

Persoalan klaim kebenaran filmis dokumenter menjadi titik tolak bagi konseptualisasi ini agar jalan keluar atas persoalan tersebut dapat dicapai. Pencapaian dilakukan dengan cara memberikan tawaran alternatif bagi cara pandang terhadap klaim kebenaran filmis dokumenter dari sudut pandang kognitif, di mana pelibatan penonton diperlukan. Tujuan pelibatan penonton adalah untuk mengamati bagaimana proses kognitif itu berlangsung melalui pengamatan penonton terhadap unsur filmis.

Sebelum penggeseran perspektif dilakukan, pertama, penyelidikan dilakukan melalui literature review untuk melihat bagaimana klaim kebenaran filmis dokumenter dirumuskan oleh empat posisi, yaitu perlakuan kreatif, representasi sosial, rekonstruksi, dan akses sosial. Dalam tahap ini, penyelidikan dilakukan dengan cara menganalisis empat posisi penting yang mengklaim bahwa kebenaran filmis dokumenter terletak pada unsur kenyataan dan aspek sineas. ${ }^{1}$ Kedua, analisis

1 Keempat posisi tersebut mengindikasikan gagasan bahwa kebenaran filmis diletakkan pada hal-hal berikut: (1) isu sosial yang ditekankan dalam shot-shot kamera dan editing gambar tertentu sebagai bentuk perlakuan kreatif (Grierson, 1972; Hilderbrand, 2009); (2) rekaman peristiwa yang disebut sebagai representasi kenyataan (Nichols, 2001; Aufderheide, 2007; Beattie, 2007); (3) rekonstruksi peristiwa yang disusun di sepanjang plot (Winston, 1999); dan persetujuan yang diperoleh dari aktor sosial untuk melibatkan mereka dalam produksi (Pryluck, 1988). ditekankan pada hal-hal yang diklaim sebagai kebenaran filmis oleh keempat posisi tersebut. Analisis dilakukan untuk mengidentifikasi ada atau tidaknya kelemahan yang memicu terjadinya persoalan sehingga hasil analisis itu menjadi titik tolak bagi penyelidikan ini. Ketiga, adanya persoalan terkait klaim kebenaran filmis yang muncul sebagai hasil analisis terhadap keempat posisi tersebut, menjadi urgensi bagi penyelidikan ini untuk mencoba menyelesaikan persoalan melalui tawaran alternatif.

\section{PEMBAHASAN}

\section{Klaim Kebenaran}

Tumbuh dan berkembangnya perhatian terhadap praktik dokumenter sering ditandai oleh munculnya isu. Isu penting yang muncul dalam perhatian tersebut salah satunya adalah isu tentang klaim kebenaran filmis (filmic truth claim). Isu tentang klaim kebenaran filmis memiliki beberapa posisi penting yang lahir dari hasil penelitian terdahulu yang meletakkan kebenaran dokumenter pada dua hubungan, yaitu (1) hubungan dokumenter dengan kenyataan dan (2) hubungan dokumenter dengan peran sineas. ${ }^{2}$ Posisi penting tersebut titik

2 Dokumenter dianggap menyajikan kebenaran saat memiliki hubungan dengan peristiwa nyata (Nichols, 2001). Dokumenter, menurut Nichols, merupakan representasi atas dunia yang didiami oleh manusia dan lingkungannya melalui suatu proses yang dinamakan reproduksi realitas. Selain itu, peristiwa nyata dianggap mengandung kebenaran ketika disajikan melalui rekaman aktual dokumenter yang dalam beberapa filmnya diperankan secara langsung oleh pelaku (aktor sosial) (Nash, 2010). 
tolak penyelidikan untuk mengungkap bagaimana pernyataan dalam posisi tersebut membuktikan bahwa kebenaran dokumenter melekat pada aspek kenyataan dan sineas.

\section{Posisi-Posisi Penting}

Perlakuan Kreatif

Posisi pertama yang lahir dari hubungan dokumenter dengan kenyataan adalah perlakuan kreatif. John Grierson (1972) dalam wawancara yang ditranskripsikan dalam Jurnal oleh Elizabeth Sussex dengan judul Grierson on Documentary: The Last Interview, menyatakan dalam sebuah dokumenter harus memuat isu tertentu dari kenyataan yang direkam. Pendekatan Grierson untuk merumuskan definisi kebenaran dokumenter adalah pendekatan praksis hingga melahirkan gaya dokumenter ekspositoris. Rumusan Grierson dikenal dengan istilah perlakuan kreatif atas kenyataan (creative treatment of actuality) (Sussex, 1972). Grierson dalam upaya mengkritisi kebenaran (truth) dalam film-film sebelumnya (yang berkembang pada era Flaherty), menyatakan pendapat bahwa kebenaran dokumenter tidak semata mengedepankan aktualitas yang di dalamnya hanya menyuguhkan peristiwa etnografis melalui adegan puitik (adegan dalam film fiksi) dengan susunan plot seperti film fiksi. ${ }^{3}$ Artinya, rekaman peristiwa juga harus menyajikan isu sosial yang dilakukan secara persuasif

3 Nanook of The North (Flaherty, 1922) merupakan film karya Flaherty yang berusaha untuk mendokumentasikan kehidupan tradisional orangorang Inuit dari Lingkaran Arktik melalui rekonstruksi pemeragaan. Konsep pemeragaan dipilih karena Flaherty menemui kendala berupa budaya inuit yang ingin ia tunjukkan sudah tidak ada lagi. Melalui bantuan Nanook, teman-teman dan keluarganya, Flaherty melakukan misi menciptakan kembali (rekonstruksi) budaya Eskimo yang "hilang" dalam serangkaian adegan dipentaskan (reenactment) (Ellis, 1989).
(Ellis, 1989). ${ }^{4}$ Selain penekanan terhadap isu sosial yang harus ada dalam dokumenter, Grierson juga menganggap dokumenter dalam karya Flaherty kurang menarik karena terlalu puitik (bersifat seperti film fiksi) dan tidak menyertakan unsur "suara". Dalam hal ini muncul dugaan bahwa yang disinggung oleh Grierson adalah ketiadaan penutur (narrator) dalam dokumenter karya Flaherty tersebut. ${ }^{5}$ Bagi Grierson, ketidakmenarikan dokumenter yang disajikan oleh Flaherty dapat diatasi dengan memberikan "perlakuan kreatif" (creative treatment of actuality). Perlakuan kreatif

$4 \quad$ Melalui pernyataan tersebut, peneliti menganggap dokumenter pada era Grierson memiliki nuansa politis karena melalui filmnya Grierson berusaha menunjukkan dan atau mengajarkan penonton tentang masalah sosial, di mana film akan lebih persuasif mengupas kedalaman cerita. Drifters (1929) merupakan salah satu film Grierson yang memiliki banyak muatan isu sosial yang nantinya akan menjadi ciri gerakan dokumenter ini, terutama penekanan pada interaksi sosial dan kegiatan sehari-hari para nelayan di laut, serta penekanan tentang pentingnya ekonomi industri perikanan melalui beberapa teknik perekaman yang inovatif (diakses dari http://www.screenonline.org.uk/ people/id/454202/; 16 Juni 2016; pukul 11:25).

5 Peneliti mengamati film Nanook of The North (Flaherty, 1922) dan tidak menemukan adanya tuturan yang dilakukan, baik oleh penutur (narrator) maupun dari aktor. Peneliti menyimpulkan bahwa penggunaan suara dalam karya Flaherty bukanlah menjadi prioritas mengingat pada era itu (tahun 1911-1930an) merupakan era perkembangan film bisu. Bahkan peneliti membaca dalam suatu catatan yang menjelaskan bahwa Flaherty pernah direkrut oleh Metro Goldwyn Mayer (MGM) untuk melakukan kerjasama produksi film berjudul White Shadows in the South Seas (1928), namun kerjasama tersebut tidak berlangsung lama karena Flaherty tidak dapat memenuhi permintaan industri film hollywod dengan kebutuhan akan sesuatu yang "menarik". Flaherty dikatakan pula menjadi frustasi karena hal ini dan proyek dilanjutkan oleh asistennya, W.S. Van Dyke. Sesuatu yang "menarik" ini memantik dugaan peneliti tentang keinginan MGM untuk menciptakan film atraktif, di mana salah satunya upayanya adalah menggunakan suara atau musik. Dugaan ini berdasarkan penjelasan yang mengatakan bahwa White Shadows in the South Seas (1928) dibuat pada akhir era film bisu dan dirilis dengan sinkronisasi musik dan soundtrack (diakses dari http://www.pbs.org/independentlens/blog/early-silentdocumentaries-real-life-adventure-cinema/; 16 Juni 2016; pukul10:23) 
dapat diterapkan melalui proses editing dengan penekanan terhadap angle (sudut pandang) tertentu yang menunjukkan adanya isu sosial, serta menambahkan penutur (narator) untuk mempertegas fokus yang dimaksud (Breitrose, 1974). Bagi Grierson dalam Sussex (1972) rekaman peristiwa yang dilengkapi dengan tuturan jauh lebih bermanfaat karena dapat mengarahkan objek kepada konsep tertentu, dan dapat juga digunakan sebagai media belajar. Ketiadaan penjelasan Grierson terkait sejauh mana kebenaran yang ditekankan dalam isu tersebut dapat dikatakan objektif, menjadikan klaim yang dikemukakan oleh Grierson memiliki kelemahan.

Sejalan dengan Grierson, Hilderbrand (2009) melalui artikel yang dimuat pada jurnal berjudul Introduction Experiment in Documentary: Contradiction, Uncertainty, Change, merujuk istilah perlakuan kreatif yang lantas dikembangkan sesuai dengan eksperimentasi dokumenter yang dilakukannya. Melalui pendekatan yang sama dengan Grierson, Hilderbrand meciptakan rumusan istilah bernama perlakuan kreatif atas pengalaman (creative treatment of experience) melalui karya dokumenter eskperimental.

"Istilah baru tersebut membuka alternatif dari sebuah film mainstream, yang melaluinya terjadi pergeseran fokus dari keadaan yang selalu menempatkan peristiwa negara di suatu dunia, kini menjadi fokus pada pengalaman manusianya" (Hilderbrand, 2009).

Kelemahan atas rumusan Hilderbrand sama dengan kelemahan atas rumusan Grierson. Hilderbrand tidak menyebutkan bagaimana rumusan itu dapat dikatakan objektif, sementara dalam suatu fakta atau pengalaman atas periwtiwa yang direkam telah disisipi perlakuan kreatif.

Kemudian Bernard (2007) dalam bukunya Documentary Storytelling, memiliki rumusan sejalan dengan pemahamanan itu. Melalui analisis tekstual terhadap proses pembuatan dokumenter, Bernard menghasilkan rumusan yang menyebutkan bahwa dokumenter harus melibatkan berbagaipilihan kreatiftentang struktur film, sudut pandang, keseimbangan, gaya, tokoh, dan lain sebagainya dalam cerita yang disajikan (Bernard, 2007). Bernard dalam perkembangan dokumenter juga berkontribusi dengan merumuskan frasa Documentary Storytelling.

Kontribusi Bernard mengindikasikan perkembangan dokumenter masa kini yang semakin beragam. Bernard menawarkan strategi untuk mencapai kualitas dokumenter melalui cerita dan keterampilan penciptaan narasi unik yang menyampaikan, tidak hanya subjek film saja, tetapi juga tema dan penulisan yang dilakukan secara jujur (Bernard, 2007). Pernyataan ini mendorong untuk melihat kembali rumusan Grierson tentang "perlakuan kreatif" yang menurutnya harus diterapkan untuk membangun nilai sebuah dokumenter. Perlakuan kreatif seolah-olah menekankan, tidak semata-mata hanya menggunakan kamera untuk merekam setiap kejadian tanpa berbuat apa-apa, tapi juga peran legitimasi seperti apa yang harus diangkat melalui teknik kreatif dalam sebuah film sehingga dapat menunjukkan isu-isu yang ditekankan. Maka rumusan Bernard yang sejalan dengan pemahamanan itu menegaskan bahwa dokumenter harus melibatkan berbagai pilihan kreatif tentang struktur film, sudut pandang, keseimbangan, gaya, tokoh, dan lain sebagainya dalam cerita yang disajikan (Bernard, 2007). Pada akhirnya, kelemahan 
dalam pernyataan Bernard adalah munculnya anggapan bahwa karakteristik dokumenter dianggap hampir sama dengan sebuah alur fiksi, yang darinya juga akan muncul beberapa hal sebagai syarat agar "diminati" oleh penonton.

Melalui pernyataannya, Bernard seakan menempatkan posisi kreativitas dokumenter yang ditawarkan sejajar dengan pemikiran Grierson. Bahkan melalui seri Documentary Storytelling-nya, Bernard mencoba mengonstruksi pola pembuatan film dokumenter untuk sekiranya berada pada relasi ini. Penegasan yang muncul dalam tawaran Bernard atas beberapa rumusan tentang apa itu cerita dokumenter, bagaimana hal itu dilakukan, dan kesalahan apa yang menjadi bahan instrospeksi, jelas ini termasuk dalam strategi Bernard untuk memberikan kontribusi dalam tradisi dokumenter.

Perlakuan kreatif sebagai posisi yang menawarkan tentang bagaimana sebuah kenyataan dibaca oleh dokumenter, dirasa cukup memiliki kelebihan dalam aspek "kemasan" atau bentuk. Berkat perlakuan kreatif, dokumenter tercipta menjadi sebuah bentuk film yang memiliki banyak muatan, seperti komunikatif dan estetis. Jika kekuatan posisi perlakuan kreatif terletak pada bentuk, maka kelemahannya terletak pada objektivitas dari bentuk itu sendiri. Misalnya praktik penggunaan tuturan dalam suatu dokumenter. Hal ini merupakan salah satu bentuk perlakuan kreatif yang diterapkan pada dokumenter. Menurut perlakuan kreatif, sebuah tuturan dianggap memiliki peran dalam upaya penyampaian kebenaran fakta dalam film (Nichols, 2001). Namun, yang menjadi persoalan dalam penggunakan tuturan tersebut adalah belum ada penjelasan komprehensif (di luar retorika Voice of God yang dirumuskan oleh Bill Nichols) bagaimana kebenaran identik dengan tuturan.

\section{Representasi sosial}

Posisi kedua yang lahir dari hubungan dokumenter dengan kenyataan adalah representasi. Merujuk pada penjelasan bab sebelumnya Nichols (2001), dalam bukunya Introduction to Documentary menyatakan bahwa dokumenter merupakan representasi sosial. Nichols menyatakan pula secara eksplisit bahwa dokumenter merupakan suatu reproduksi realitas atas situasi manusia dalam dunia yang didiaminya (Nichols, 2001). Nichols menggunakan empat pertimbangan sudut pandang dalam pendekatannya untuk mendefinisikan kebenaran dalam dokumenter. Empat sudut pandang itu adalah: (1) institusi; (2) praktisi/pelaku; (3) teks (film/video); dan (4) penonton (Nichols, 2001). Namun, Nichols belum secara tegas menyebutkan bahwa representasi sosial merupakan aspek yang objektif untuk mengklaim kebenaran dalam dokumenter.

Aufderheide (2007) dalam bukunya Documentary Film a Very Short Introduction, menyatakan bahwa peristiwa yang terjadi pada hubungan dokumenter dengan kenyataan merupakan suatu representasi dan realitas. Namun, melalui definisi yang dibangunnya Aufderheide juga mempermasalahkan batas antara fakta dengan fiksi. Bagi Aufderheide, sebuah film dokumenter merupakan film yang bercerita tentang kehidupan nyata dengan klaim kebenaran yang selalu menjadi polemik. Artinya bagaimanapun film itu memberikan representasi secara jujur dan dengan itikad baik, tetap akan menjadi bahan diskusi yang tidak pernah selesai. Pernyataan Aufderheide ini menunjukkan bahwa representasi realitas 
belum cukup objektif untuk mengklaim kebenaran dalam dokumenter.

Keith Beattie dalam bukunya yang berjudul Documentary Screen NonFiction Film and Television menyatakan bahwa sebuah dokumenter merupakan tindakan perekaman atas peristiwa nyata yang terjadi sehingga hasil rekaman itu dianggap sebagai representasi kenyataan (Beattie, 2004). Representasi kenyataan inilah yang dianggap Beattie sebagai kebenaran dalam dokumenter. Jika hasil tindakan perekaman atas peristiwa nyata diklaim sebagai kebenaran, maka masalah yang muncul atas posisi tersebut berkenaan dengan objektivitas. Saat dokumenter menyajikan ulang suatu peristiwa, sulit ditentukan bahwa dokumenter memang menyajikan dirinya sebagai realitas. Dokumenter sebagai representasi budaya hanyalah sebagai simulacra. ${ }^{6}$ Akhirnya, perlu digarisbawahi bahwa representasi juga memiliki persoalan terkait klaim kebenaran.

Secara teoretis, perbedaan antara posisi perlakuan kreatif dengan representasi terletak pada peran kenyataan dalam menyajikan kebenaran dokumenter. Perlakuan kreatif merupakan upaya menciptakan atribut tertentu dalam suatu peristiwa sehingga muncul isu yang seolah menyatakan bahwa situasi tertentu telah muncul dalam peristiwa itu dan berkembang menjadi suatu fenomena. Sementara representasi menganggap bahwa dokumenter merupakan

6 Baudrillard mengungkapkan bahwa dalam masyarakat postmodern, simulacra (simulacral simulacrum merupakan konsep penting dalam seni visual yang mempersoalkan hubungan kompleks antara realitas dan simulasinya melalui reproduksi mekanis selanjutnya melalui produksi elektronik dunia virtual) tidak mencontoh realitas pra-ada, melainkan benarbenar memindahkan realitas. Hiperealitas didefinisikan oleh Baudrillard sebagai suatu tatanan representasi yang didasarkan pada ilusi yang kekuatannya meningkat dalam proporsi yang sebenarnya hingga kemampuannya untuk membuat kita lupa bahwa itu benar-benar ilusi (Baudrillard dalam Cavallaro, 2004). rekaman yang menyajikan ulang suatu kenyataan. Kenyataan dokumenter dalam perspektif representasi memiliki arti sebagai sesuatu yang telah dipindahkan menjadi bentuk baru berupa rekaman. Artinya, representasi tidak mengubah kenyataan dalam proses perekaman, namun representasi melakukan pemindahan kenyataan kepada bentuk baru bernama dokumenter. Seperti Nichols menyatakannya sebagai berikut.

"Dokumenter, kemudian menawarkan kemiripan aural dan visual atau representasi beberapa bagian dari dunia sejarah. Mereka berdiri untuk atau mewakili pandangan individu, kelompok, dan institusi" (Nichols, 2001).

\section{Keahlian Sineas}

Posisi pertama yang lahir dari hubungan dokumenter dengan sineas adalah keahlian sineas. Keahlian sineas dalam bidang tertentu dianggap kompeten dalam melakukan rekonstruksi (Ruby, 1992). Winston dalam Aaltonen \& Kortti (2015) melalui posisi ini menemukan model yang dinamai "rangkaian kesatuan rekonstruksi” (reconstruction continuum).

Aaltonen \& Kortti (2015) dalam artikel jurnal yang berjudul "From Evidence to Re-enactment: History, Television and Documentary Film", menyatakan bahwa sejarah meletakkan fakta peristiwa pada konsep rekonstruksi yang melibatkan keahlian sineas untuk menunjukkan kebenaran. Dalam hal ini, sineas yang memiliki keahlian profesi misalnya, dianggap kompeten untuk menemukan dan menciptakan materi bagi dokumenter melalui campur tangannya terhadap peristiwa yang direkam. Melalui analisis pragmatis terhadap salah satu karya dokumenter mereka, Aaltonen 
dan Kortti ingin menunjukkan kontribusi sejarah dalam pembuatan film dokumenter pada umumnya. Selain itu juga untuk menunjukkan bagaimana perkembangan film dokumenter telah memengaruhi sifat dokumentasi sejarah yang ditayangkan di televisi. Aaltonen dan Kortti menunjukkan bahwa keahlian sineas dokumenter berkontribusi dalam penyampaian kebenaran melalui rekonstruksi sejarah, namun masih belum menyentuh wilayah objektivitasnya. Hasil rekonstruksi sejarah dalam dokumenter masih dipertanyakan objektivitasnya mengingat sineas dalam hal ini melakukan campur tangan untuk membangun suatu cerita.

Ruby (1992) dalam artikel jurnal berjudul Speaking For, Speaking About, Speaking With, or Speaking Alongside: An Anthropologycal and Documentary Dilemma, menyatakan bahwa tindakan sineas dengan menggunakan keahlian yang dimiliki, seperti profesi, akan memudahkan untuk melakukan klaim kebenaran pada dokumenter. Jay Ruby menyatakan bahwa seorang sineas dokumenter yang memiliki keahlian atau profesi tertentu berusaha menemukan dan berpikir tentang citra visual sebagai sarana konstruksi sosial melalui dokumenter (Ruby, 1992).

Sejalan dengan Ruby, Rosen \& Renov (1993) dalam esai yang berjudul Document and Documentary: On the Persistence of Historical Concepts, menyatakan bahwa sebuah dokumenter merupakan rekonstruksi sejarah yang dibangun oleh sineas untuk menghadirkan kenyataan lewat tradisi dan teknologi secara indeksikal (Rosen \& Renov, 1993). Berdasarkan pernyataan Ruby dan Rosen, keahlian sineas sebagai posisi yang berada dalam hubungan antara dokumenter dan sineas memiliki kelemahan berupa kekhawatiran tentang adanya penyubjekan. Artinya, keahlian sineas dikhawatirkan justru menjadikan dokumenter sebagai subjek yang telah direkonstruksi untuk mengakomodasi kepentingan sineas.

\section{Akses Sineas}

Posisi kedua yang lahir dari hubungan dokumenter dengan sineas adalah akses terhadap pelaku (aktor). Posisi ini merumuskan model bernama persetujuan (consent). Calvin Pryluck dalam esai berjudul "Ultimatly We Are All Outsiders: The Ethics of Documentary Filming", menyatakan bahwa persetujuan merupakan dasar tumbuhnya kepercayaan partisipan untuk bersedia berperan sebagai aktor sosial (Pryluck \& Rosenthal, 1988). Awalnya, persetujuan dibutuhkan dalam penciptaan dokumenter dalam konteks etika. Saat ini persetujuan cenderung menjadi hal penting untuk menyajikan kebenaran (Pryluck \& Rosenthal, 1988). Kecenderungan itu mengacu pada pernyataan Sanders (2012) dalam artikel jurnal berjudul "The Aggie Will Come First Indeed. A Survey on Documentary Filmmakers Dealing With Participants", menyatakan bahwa keterbukaan, kepercayaan, dan persetujuan dari pelaku bagi pembuat film untuk menginterpretasi adalah kontribusi penting. Sanders menafsirkan pola ini sebagai situasi kepercayaan dan pemahaman melalui komunikasi yang sedang berlangsung dengan istilah kerjasama yang kooperatif (Sanders, 2012).

Persetujuan memang dibutuhkan dalam penciptaan dokumenter, namun kekhawatiran akan subjektivitas sekali lagi menjadi kelemahan posisi ini. Persetujuan dalam hubungan antara dokumenter dan sineas pada akhirnya berperan menjadi kebenaran yang kooperatif. Artinya, kebenaran yang diperoleh melalui kesepakatan 
antara sineas dan pelaku, hasilnya belum tentu menjadikan dokumenter itu memuat kebenaran.

Secara teoretis, perbedaan antara posisi keahlian dengan akses sosial terletak pada tindakan sineas. Tindakan sineas dengan menggunakan keahlian yang dimiliki, seperti profesi, berusaha mengidentikkan upaya yang dilakukan sebagai klaim kebenaran. Seperti ditegaskan oleh Jay Ruby berikut ini.

"Pembangunan argumen yang disajikan di sini adalah konsekuensi dari identitas saya sebagai seorang antropolog yang tertarik pada media bergambar sebagai sarana reproduksi budaya. Saya menemukan dan berpikir tentang citra visual sebagai bentuk konstruksi sosial yang komunikatif dan produktif' (Ruby, 1992).

"Film yang diproduksi secara kooperatif dan subjek yang dihasilkan oleh film adalah signifikan karena mereka mewakili pendekatan dokumenter dan film etnografi, serta berbeda dengan praktik yang dominan” (Ruby, 1992).

Sementara tindakan sineas yang menggunakan akses sosial untuk mendapat persetujuan pelaku merupakan aspek untuk menunjukkan kebenaran dokumenter melalui kerjasama yang kooperatif. Seperti ditegaskan oleh Willemian Sanders berikut ini.

"Komunikasi yang berkelanjutan dan memiliki timbal balik, memberi banyak kontribusi. Keterbukaan, kepercayaan, dan persetujuan bagi pembuat film untuk menginterpretasi adalah kontribusi penting. Saya menafsirkan pola ini sebagai situasi kepercayaan dan pemahaman melalui komunikasi yang sedang berlangsung. Saya mendefinisikan pola ini sebagai kerjasama yang kooperatif (Sanders, 2012).

\section{Pendekatan Film Kognitif untuk Menyelidiki Kebenaran Filmis}

Penentuan pendekatan yang digunakan merupakan bagian dari konseptualisasi yang bertujuan untuk mengungkap sisi lain kebenaran dalam dokumenter yang tidak hanya ditempatkan pada (1) perlakuan kreatif; (2) representasi; (3) keahlian sineas; dan (4) akses sosial. Sisi lain kebenaran dokumenter dapat ditemukan melalui upaya penyelidikan dengan perspektif baru untuk memandang dokumenter melalui hubungan antara dokumenter dengan penonton. Perspektif baru yang menempatkan relasi antara dokumenter dan penonton bertujuan untuk melihat kebenaran filmis berdasarkan pengalaman penonton. Terdapat dugaan bahwa keterpercayaan merupakan hasil dari pengalaman penonton dalam pembacaannya terhadap teks (unsur filmis) melalui petunjuk filmis. Untuk membuktikan dugaan tersebut, konseptualisasi ini memilih pendekatan film kognitif berupa metode pemahaman (understanding), untuk mengurai pengalaman yang berlangsung. Merujuk pada pernyataan Bordwell dan Carroll, pendekatan film kognitif memberikan ruang bagi dokumenter untuk dikonseptualisasi ulang sehingga muncul posisi alternative bagi pembacaan kebenaran filmis (Plantinga, 1997).

Konsep pemahaman (understanding) digunakan dengan alasan: (1) Dokumenter sebagai film menyajikan isyarat, pola, dan kesenjangan yang membentuk kesadaran penonton melalui schemata. Artinya, isyarat naratif pada film dan pembatasan aktifitas 
konstruksi cerita pada penonton memungkinkan bagi mereka untuk membentuk ruang, waktu, dan dimensi sebab-akibat terhadap representasi mental tunggal yang koheren (Buckland, 2004); (2) Film memproduksi beberapa pengaruh. Pengaruh tersebut berkisar pada satu perseptual dan kepada satu konseptual (bagaimana penonton bisa mengetahui bahwa $\mathrm{X}$ menunjukkan kemarahan) dimana penafsiran film berusaha untuk menjelaskan dimana unsur itu memainkan pengalaman penonton (Bordwell, 1991). Artinya, ketika setiap film memberikan pengalaman yang bermacammacam bagi penontonnya, dapat menyusun makna secara individu dari apa yang mereka tonton; dan (3) Pembacaan dokumenter salah satunya adalah mengungkap tentang unsur keterpercayaan sebagai kebenaran.

Metode pemahaman (understanding) dalam operasionalnya memerlukan disposisi yang melibatkan kehidupan sehari-hari (everyday life) untuk membaca teks. Dalam kasus penonton dokumenter di Indonesia, misalnya, penonton memiliki cara sendiri dalam membaca teks-teks filmis pada tayangan tersebut. Penonton di Indonesia memiliki modal pengalaman kehidupan sehari-hari berbentuk kepercayaan terhadap, misalnya, takhayul. Hal ini telah diungkapkan oleh Bernard Arps sebagai berikut.

"Setiap daerah dan kelompok etnis di Indonesia memiliki keyakinan takhayul tersendiri dan cerita misteri tentang kejadian supranatural. Segala jenis perdukunan, takhayul, benda mistis, hantu, dan makhluk gaib dalam jumlah banyak merupakan bagian tak terbantahkan dari keyakinan dan budaya orang Indonesia” (Arps, 2006).
Oleh karena itu, meskipun pemahaman itu kadang dianggap tidak rasional, buktinya penonton dapat mencerna narasi tersebut karena disposisi dari pengalaman kehidupan sehari-hari terhadap teks-teks filmis. ${ }^{7}$ Disposisi itu memungkinkan penonton memiliki pengalaman kontempaltif dalam membaca teks (unsur filmis). ${ }^{8}$

\section{SIMPULAN}

Wacana yang muncul pada satu periode menuju periode berikutnya memberi peluang penegasan bahwa dokumenter bersifat dinamis. Sifat dinamis itulah yang menjadikan dokumenter memiliki peluang untuk diselidiki dan dikaji ulang dalam upaya penyelesaian problem di dalamnya. Upaya penyelesaian problem dilakukan dengan cara mengkonseptualisasi pertemuan antara dokumenter dan penonton di dalam ruang yang dibangun melalui keterpercayaan sebagai cara pandang alternatif terhadap kebenaran filmis. Keterpercayaan inilah yang nantinya menjadi posisi alternatif yang akan ditawarkan melalui penelitian selanjutnya.

$7 \quad$ Bernard Aprs dan Katinka van Heeren (2006) telah membahas bagaimana penonton Indonesia merespons tayangan televisi ber-genre horror dengan mengambil contoh tayangan berjudul "Pemburu Hantu". $8 \quad$ Kontempatif dalam konteks dokumenter adalah presentasi subjek melalui media sinematik dibaca melalui pengamatan peristiwa dari luar, dengan cara terpisah, terlepas dari komunikasi dengan pikiran sineas tentang berbagai peristiwa yang direkam (de Caro dan Terrone, 2016). 


\section{KEPUSTAKAAN}

Aaltonen, J., \& Kortti, J.(2015). “From Evidence to Re-enactment: History, Television and Documentary Film." Journal of Media Practice, 16(2), 108-125.

Arps, B. dan K. V. H. (2006). Ghosthunting And Vulgar News: Popular Realities on Recent Indonesian Television. yogyakarta: Pustaka Pelajar.

Aufderheide, P. (2007). Documentary Film: A Very Short Introduction. oxford: Oxford University Press.

Beattie, K. (2004). Documentary Series: Nonfiction Film and Television. New York: Palgrave Mac Millan.

Bernard, S. . (2007). Documentary Storytelling. Oxford: Elsevier.

Bordwell, D. (1991). Making Meaning: Inference and Rhetoric in the Interpretation of Cinema. USA: Harvard University Press.

Buckland, W. (2004). The Cognitive Semiotics of Filmitle. Cambridge: Cambridge University Press.

dan Breitrose, H. (ed). (1974). Documentary Diary. Film Quarterly, Vol. 27, N, 52-54.

Ellis, J. C. (1989). The Documentary Idea: A Critical History of English-Language Documentary Film and Video. New Jersy: Prentice Hall.

Hilderbrand, L. (2009). NoIntroduction Experiment In Documentary: Contradiction, Uncertainty, Change. Millenium Film Journal.

Nichols, B. (2001). Introduction to Documentary. Bloomington: Indiana University Press.

Plantinga, C. . (1997). Rhetoric and Representation in Nonfiction Film. Cambridge: Cambridge University Press.

Pryluck, C., \& Rosenthal, A. (Ed.). (1988). New Challenge for Documentary: The Voice of Documentary. Berkeley: University of California.

Rosen, P., \& Renov, M. (Ed.). (1993). Theorizing Documentary. London: Routledge.

Ruby, J. (1992). Speaking For, Speaking About, Speaking With, or Speaking Alongside: An Anthropologycal and Documentary Dilemma. Journal of Film and Video, Vol. 44, N(International Issues (Spring andSummer)), 42-46.
Sanders, W. (2012). The Aggie Will Come First Indeed. A Survey on Documentary Filmmakers Dealing With Participants. New Review of Film and Television Studies, Vol. 10, N, 387-408.

Sussex, E. (1972). "Grierson on Documentary: The Last Interview." Film Quarterly (Archive), 26(1). 